\title{
Psalm 137: Perspectives on the (NeUro-) PSyChology OF loss
}

Author:

Hennie Viviers $^{1}$

\section{Affiliation:}

${ }^{1}$ Department of Religion,

University of Johannesburg,

South Africa

\section{Correspondence to:}

Hennie Viviers

email:

hviviers@uj.ac.za

\section{Postal address:}

Department of Religion,

University of Johannesburg,

PO Box 524, Auckland Park

2006, South Africa

\section{Keywords:}

bereavement; exile; neuropsychological imperative; neural networks; Psalm 137

\section{Dates:}

Received: 17 May 2010

Accepted: 24 Aug. 2010

Published: 29 Oct. 2010

How to cite this article: Viviers, H., 2010, 'Psalm 137: Perspectives on the (neuro-) psychology of loss', Verbum et Ecclesia 31(1), Art. \#397, 7 pages. DOI: 10.4102/ ve.v31i1.397

\section{This article is available} http://www.ve.org.za
(C) 2010. The Authors. Licensee: OpenJournals Publishing. This work is licensed under the Creative Commons Attribution License.
ABSTRACT

The neuro-psychological imperative first implies the formation of neural networks through exposure to the external environment, both physically and ideologically, giving us our 'selves'. It in turn implies the projection of this internal world onto the outer to achieve neuro-environmental consonance. Situations like bereavement, immigration or exile break down this consonance and are accompanied by strong negative emotions. When viewing Psalm 137 through the lens of the neuro-psychological imperative, its intense experience of the loss of land (and 'self') becomes transparent as this psalm vividly recalls the devastating experience of the Babylonian exile. The shocking end of the psalm, detailing the desire for the brutal annihilation of enemy infants, expresses the understandable ideological drive of the exiles to, ironically, retrieve their lost 'selves.' Although understandable as an upholding of the established internal world, the manner in which this is to be achieved is not to be emulated by modern civilised societies.

\section{INTRODUCTION}

In 1959, Eva Hoffman, a Polish girl and her parents voluntarily immigrated to Vancouver, Canada. She articulated the overwhelming nostalgia for her lost home as follows:

... the country of my childhood lives within me with a primacy that is a form of love ... It has fed me language, perceptions, sounds, the human kind. It has given me colors and the furrows of reality, my first loves. The absoluteness of those loves can never be recaptured. No geometry of the landscape, no haze in the air, will live in us as intensely as the landscapes that we saw as the first, and to which we gave ourselves wholly, without reservations.

(Wexler 2006:175)

Approximately 2500 years earlier, the poet of Psalm 137 expressed something similar: 'By the rivers of Babylon we sat and we wept when we remembered Zion ...' Likewise, this psalm also overflows with intense emotion (Gemser 1968:199) and captures the shocking emotional experience of immigration. In this case, however, immigration takes the form of a forced exile by the Judeans' enemy of the time, the Babylonians. Immigration is quite similar to the experience of bereavement and accordingly takes time and effort to overcome and to become fully adapted to the new surroundings (Wexler 2006:6-7; Cezar Garza-Guerrero 1974:418).

The emotionality of Psalm 137 involves not only a few superficial feelings that come and go which we can control as we please; it has a much deeper base. Psalm 137 elicits intense and tenacious feelings which can be explained by a neurobiological foundation responsible for the sensation of being captivated by feelings wherein we feel that our feelings control us and not the other way around. In 2006, the neuroscientist cum-psychiatrist Bruce Wexler wrote an illuminating book, Brain and Culture: Neurobiology, Ideology, and Social Change and his insights predominantly inspired this contribution. In this book he lays bare what he calls the neurobiological imperative, upholding our mental worlds (consciousness) and the latter, in turn, confirming and keeping alive the neurobiological imperative. The brain-mind, called thus to indicate the complex functional interaction between its physicality and mentality, ${ }^{1}$ is so intricately linked with its sensory environment and our biology so fundamentally social, that '... to speak of a relation between the two suggests an unwarranted distinction. It is our nature to nurture and be nurtured' (Wexler 2006:13; Pyysiäinnen 2001:215). Kuberski (2000:11) aptly formulates this concept in a similar vein: 'a brain without a world to cognize is not a brain'. Our neurobiology is constantly shaped by the outer world (during childhood) and it in turn shapes the outer world (during adulthood) to maintain internal-external or neuro-environmental consonance (Wexler 2006:18). Neuro-environmental consonance is what gives us comfort, a feeling of belongingness and identity confirmation. The neurobiological imperative also aptly provides a deep-seated reason why we embrace our ideologies and values to the extent that we do, even defending them through physical violence (e.g. Ps 137:7-9). Through our established neurological schemata we become 'wired' to do so and, to a certain extent, do not give us much choice. However, at the same time we are not prisoners of our neurobiology. Through our consciousness we are more than our physicality; we are also able to're-wire' our neurobiology to prompt us into new behaviours.

In what follows, Wexler's insights on the establishment of the neurobiological (neuro-psychological) ${ }^{2}$ imperative will be highlighted and its assertion onto the outer world will be laid bare. Psalm 137 will then be viewed through the lens of the neuro-psychological imperative to explore the depth and tenacity of this psalm's emotional experience of the exile.

1.The brain makes the mind, it remains an enigma how '... a non-material mind can rise from mere biological functions; how the flesh and blood machinery of the brain can suddenly become "aware" ' (Newberg et al. 2001:32). Brain and mind exist as an inseparable unity, therefore the use of the term 'brain-mind'.

2. When Wexler (2006:1) uses the term 'neurobiological', the psychological is implied as well: 'Neurological and psychological function are two sides of a coin ...' In this contribution, I prefer to use the term 'neuro-psychological' to capture both the deeply integrated physiological and mental aspects of our being. 


\section{THE FORMATION OF THE NEURO- PSYCHOLOGICAL IMPERATIVE}

Wexler (2006:19-36) provides a concise and reader friendly summary of the complexities of the brain-mind. The human brain consists of approximately 100 billion neurons or nerve cells. ${ }^{3}$ Each of these neurons has thousands of chemical docking stations on its outer surface (i.e. dendritic branches) where neurotransmitters (chemicals) 'dock'. These evoke electrical impulses running through the dendritic axons and in turn exit the neuron chemically to continue the information transfer process to its neighbouring neurons. All of these thousands of electro-chemically 'firing' messages happen within milliseconds. The messages received are interpreted mentally, that is, cognitively ('knowing'), emotionally ('feeling') and through memory ('recall'), enabling us to react in appropriate ways according to whatever the message might be. Mental functions are not mediated by single neurons, but rather by larger groups or assemblies of neurons that become structured functionally with complicated communicative pathways. Each individual's neural networks differ, even in siblings, so that we each have a remarkable, unique and meaningful representation of the 'world'. These neural networks manifest common agerelated behaviors. ${ }^{4}$ So remarkable is the functional complexity of the brain that if neuronal activity is inhibited in one area, neighbouring neural networks can take over functions in a limited way:

... in young children who have had the entire left side of their brain surgically removed for treatment of otherwise untreatable seizures, all functions become localized in the remaining right hemisphere. Even the language function ...

(Wexler 2006:26)

Mammalian brains evolved a limbic structure and system around the 'reptilian core' and it is this limbic structure that is very much the centre for familial and social behaviors. In addition, humans have developed their very large frontal and parietal lobes creating '... an unprecedented opportunity for environmental shaping of uniquely human aspects of brain function' (Wexler 2006:36). This process of environmental input continues up until approximately 25 years of age. ${ }^{5}$

For the brain to develop normally and to function properly, it needs constant sensory stimulation. This is not a choice but a necessity (Wexler 2006:90). The stage between early childhood and early adulthood (puberty or adolescence) is critical in the formation of brain structures and functions and is described by Wexler as the time of neuronal plasticity (2006:118). This is the period wherein neural network growth ${ }^{6}$ takes place in order to become established, while still being quite susceptible to changes, both physically and culturally. We know for example how young children adamantly defend their convictions, seeing everything in black and white, but we are also aware how quickly their views can change. Once adulthood sets in, the

3.Kuberski, writing on the intricacies of consciousness, makes the point that a single neuron is infinitely more complex than anyone would ever have imagined; it has a ... mind of its own ...' (2000:12 citing Scott).

4.The 'theory of mind' mental tool (ToM), for instance, which enables us to 'mind read' others (their probable goals, motivations, desires, etc.), is not developed in children younger than more or less five; older people have stronger mind-reading capabilities than younger people. For a more detailed account on ToM see Barrett (2004:31 44). In order to also explain the differences betwe cultures in spite (2004:31-44). In order that humans the same bran-minds that humans share es: it is what provide for variation as well ... however, variation is not infinite

5.Other than the human species, we are all aware of how quickly the offspring of nonhuman mammals mature in order to survive independently.

6.Wexler (2006:56-57) explains the importance of $\mathrm{N}$-methyl- $D$-aspartate (NMDA) receptors for neural growth. The neurotransmitter glutamate, released by sensory relay neurons from the brainstem, activates cortical neurons by attaching to the NMDA receptors on these nurons. Researchers believe that NMDA receptors directy activats on the double in immature animals than in adults. This confirms the malleability of the immature brain, equipped to grow and develop optimally. neuro-plasticity of the brain-mind becomes less as adults become very established in their habits and convictions. Views are only reluctantly changed during adulthood. If a lack in sufficient sensory stimulation exists during the pre-adult period, neurons die, become smaller, less synaptic connections are generated and the individual becomes deprived of the functions these networks should have provided. For example, people who have suffered from congenital cataracts since childhood and have had these problems rectified in adulthood, still have visual malfunctions in spite of the eyes or eye functioning mechanically in a normal way. The neural networks that should have been there but are not, lead to problems with depth perception, impaired visual working memory (i.e. patients cannot remember what they saw), impaired visual recognition and differentiation of objects (e.g. to keep on mistaking the same size cat for the dog and vice versa), etcetera. The same kinds of impairments due to sensory deprivation have also been noted in several animal studies. Sensory deprivation also has psychological effects:

When ... in conditions of sensory deprivation, people seek stimulation and soon become depressed and anxious. Moreover, their brains no longer work as effectively; they have illusory sensory experiences, altered perceptual thresholds, and difficulty with certain types of problem solving.

(Wexler 2006:83)

Narrowing the focus from general stimulation of the brainmind to that of the social environment, specifically, the mother, parents, family and cultural environment become indispensable for the proper formation of the young pre-adult human. This also confirms the view that our fellow human beings attract our attention far more than anything else (Guthrie 1993). Wexler refers to the mother-infant relationship as an integrated dyadic unit (2006:2, following the famous Russian psychologist Vygotsky). Whereas in animals communication with infants is very much olfactory, ${ }^{7}$ communication becomes very visual and auditory for humans. Exposure to exaggerated facial expressions and vocal displays of basic emotions, present crossculturally (Ekman 2008:95-123), activates the limbic system (orbitofrontal cortices, amygdale, etc.), ${ }^{8}$ the basis or 'centre' for family and social behavior. Very young infants are sharply focused on their mother's face and voice. There is a loss of neurobiological structure in the infants of both nonhuman mammals and humans deprived of natural parenting. Wexler (2006:100) states succinctly: 'Linked with their parents in dyadic and family systems, infants develop physiological patterning that is influenced by and often similar to the patterns of their parents.' Children's 'circuitry' is shaped by what adults are interested in and hold as important, both from their own childhood experiences as well as the culture they form part of. As an example, in a certain sense, parents equip their children with the rational capacity of their frontal lobes in matters of problem solving and in making important decisions and this is probably why even senior adults often claim to do things the way their parents have done and taught them. ${ }^{9}$ Children learn through imitation ${ }^{10}$; language, for instance, a cultural phenomenon for which we have evolved an innate capacity, is learned through imitation (Wexler 2006:121). The neuro-plasticity of the young brain-mind remarkably comes to the fore in the learning of a new language, whilst the adult finds this rather difficult. Apart from language, children also internalise the values and

7. The 'social' neuropeptide Oxytocin, unique to mammals, plays an important role in rats to suppress the mother's aversion to the odor of her newborns. It also facilitates pair bonding between males and females. Although Oxytocin is present in humans, it is found in other brain regions where its receptors are situated (Wexler 2006:86it is found in
$88,96)$.

8.Kagan (1994:7-24) provides detail of some of these 'emotional' pathways.

9.How true is the expression 'a chip off the old block,' when also viewed from a neuropsychological perspective?

10.'Mirror neurons' that facilitate imitation have been demonstrated in human infants even as young as two weeks old as they imitate the sticking out of tongues and other imitative behaviors, that is reciprocal vocalisation between mothers and their 3-month-old infants (Wexler 2006:114). 
ideologies of their immediate social and cultural environment and are more than often very conservative in their convictions. To embrace one's ideologies and constituted reality and elevate them above criticism is part and parcel of adult life (McCutcheon 2000:207). Children learn through play, ${ }^{11}$ which is actually more of a cognitive process than a motor activity and of which formal schooling is an extension. Wexler (2006) summarises the shaped young adolescent as follows:

Adolescents ... are occupied with ... integrating internal structures derived from multiple sources into a functionally coherent whole, and articulating a personal ideology that leads to a niche in the general social matrix that is consistent with the internal structures.

(Wexler 2006:136-137)

Therefore the young adult requires an identity or a self and a neuro-psychological makeup that determines the way they will conceptualise their reality, feel, make decisions and generally live their life.

A few remarks need to be added about the role of emotions, especially in the confirmation and protection of the young adult's acquired ego identity, shaped as we have just seen, in order to also understand the depth of the emotions experienced in Psalm 137. The young child is not able to articulate particular feelings adequately, but is very well equipped to experience them. Adults' skewed faces and gurgling sounds are soon properly articulated, guiding and providing their maturing child with the same emotional experiences, of things either harmful or beneficial that fill their environment and are of interest to them, for example, sounds, foods, places, et cetera. Described by Manstead as psychological states,$^{12}$ emotions are therefore always object oriented in contrast to moods that are not (e.g. irritation, boredom; Manstead 2008:xxix). Love, joy, surprise, anger, sadness and fear are usually identified as basic emotions. ${ }^{13}$ Emotions are also markedly social and shared with others (Manstead 2008:xxxiii) and have come a long way since our evolutionary past to enhance our species' adaptivity (Ekman 2008:96-97). We become emotional about things important to us in terms of values and goals to which we are committed to and embody our identity. Vengeance for instance, borne out of anger, '... is a way of repairing damage to one's demeaned .. ego identity' (Lazarus 2008:45, 63; Cesar Garza-Guerrero 1974:418, Leavitt 1996:528; Ps 137).

\section{THE ASSERTION OF THE NEURO- PSYCHOLOGICAL IMPERATIVE}

As a child moves into adulthood the neuro-plasticity of the brain decreases. In contrast to this malleable, rather passive pre-adult that is being influenced by the outer reality in order to form their inner reality, the adult has an established and stable internal world that determines how the external world is perceived and treated. The neuro-psychological circuitry that has now been established not only gives rise to the concept 'self', but becomes an imperative in how to impact on and shape the external world. Humans strive, as Wexler has pointed out, for internal-external consonance (2006:5). It makes them comfortable and gives them self-acknowledgement and overall meaning in life; they therefore do not have much of a choice other than to constantly match the external world with their internal world. Seeing that

11. Reptiles do not play with their young, but mammals do (Wexler 2006:132).

12.Manstead (2008:xxix), provides the following working definition of emotions: 'Emotions can be defined as psychological states that comprise thoughts and feelings, physiological changes, expressive behaviors, and inclinations to act. The precise combination of these elements varies from emotion to emotion, and emotions may or may not be accompanied by overt behaviors. This complex of states and behaviors is triggered by an event that is either experienced or recalled. Emotions are both bodily (e.g. C. Darwin, W. James) and culturally (e.g. C. Geertz) derived. Leavitt (1996:526) verbalises as follows: 'emotions are felt in bodily experience, not just known or thought or appraised'; see also Ekman (2008:106).

13.Psychologists differ on the number of emotions, as well as so-called 'families' of emotions and the characteristics of emotions (e.g. Manstead 2008:xxx; Ekman 2008; Lazarus 2008) the neural networks are set and not easily changeable, the world has to be changed accordingly as the internal world is projected onto the external.

The learned internal structures filter, select and evaluate sensory input that is consistent with them (Wexler 2006:154-155) - we 'see' what we want to see, or perhaps, what we are forced to see. People are so strongly committed to their idiosyncrasies that their own view will be physically forced onto others if deemed necessary. In order to avoid such extremes, people seek out like-minded others to associate with. This is aptly illustrated in sports fans who might disagree on many things, but bond unconditionally and agree completely that their team should be successful. They wear the same clothes as their teams as token of their loyalty and even develop the same hormonal levels as the players they are watching and identifying with. ${ }^{14}$ Internalexternal consonance is also achieved by spontaneously seeking out the familiar which is experienced as pleasurable (Zajonc 1970), ${ }^{15}$ irrespective of the objective qualities of that which is familiar (Wexler 2006:155), whether it be a face, music, food, building, landscape, etcetera. The blind allegiance to a political party on own soil, because it was the lifelong party of the parents (family), is well-known. Even if the particular political party fares badly at the polls and this information creates dissonance with internal convictions, it is nevertheless defended without question. The opposition's victory is usually discredited, ignored, re-interpreted or forgotten (Wexler 2006:160, 169) to alleviate the feeling of dissonance. A sudden switch to the new party becomes near impossible as the internal representations reject it. The latter has to change first and this, as has been pointed out, does not come easy or inexpensively in adulthood.

There are, however, situations where seeking out likemindedness and the familiar is not possible and a disjunction or misfit with the internal structures becomes severe and tenacious. This is very applicable to what we read in Psalm 137. Wexler names bereavement and immigration as two such situations where the emotional experiences are remarkably similar. What is lost when the death of a loved one occurs, for instance a spouse? Wexler (2006) lucidly encapsulates the answer to this question:

it is seeing, hearing, smelling, touching, and being touched by the other person. In other words, a large part of the interpersonal sensory environment that had become a large part of the internal representation of the external world is now gone ..

(Wexler 2006:172)

It is also the feedback of the same worldview, values and ideologies, confirming the remaining partner's ego identity that is lost. And therefore '... part of oneself has died' (Wexler 2006:173). Apart from all the emotions during mourning, the 'reviving' or remembrance of the deceased through imitation, 'assuming his or her behavior, characteristics, and even medical symptoms' (2006:173), becomes a desperate retrieving also of the self. It requires 'grief work' (Freud) of more or less a year to overcome the grief, an undoing of the familiar (e.g. spouse-orientated) neuronal interconnections and the formation of a new internal world. What is lost during immigration? Wexler again states: 'The objects and activities of everyday life are most profoundly missed: food; music; social customs; language; landscape; and street corners, houses, and cafes ...' (2006:179). Immigration to a large extent implies the loss of one's identity (Leavitt 1996:528). Whether immigration is voluntary or forced (e.g. the Babylonian exile) will determine the intensity of the emotional experiences and also the adaptation of the immigrant (Ahktar 1995:1077). In

14. The fascinating psychological bond that exists between sports fans and their teams and the consequential bodily effect is tellingly exemplified by Wexler (2006:147). He points out that the testosterone levels of Brazilian soccer fans rose by $28 \%$ after winning the 1994 World Cup, while those of Italy dropped by $27 \%$, with no instrumental contact between fans and players.

15.See the striking title of R. Zajonc's article, 'Brainwash: Familiarity breeds comfort' and the defense of his basic proposition in this article: ' the mere repeated exposure of an unfamiliar stimulus is enough to increase one's attraction to that exposure of an un that stimulus. Repetizing strangers more acceptable' (1970:33). Our exposure to and enjoyment of nove experiences are limited because our internal networks demand what is tried and tested. 
order to retain something of an internal-external consonance, immigrants usually create a microcopy of the familiar things 'back home', such as food, social customs, music and so forth This is a non-violent way of the neuro-psychological imperative asserting itself and of denying the other culture. A total rejection of the other culture and all it represents in terms of its values, ideologies and symbols, can easily translate into a violent extermination thereof, of which we have a sad history since time immemorial (Wexler 2006:183-231). On the other hand, the new culture can in time (as is the case with bereavement) become appreciated, embraced and internalised to become part of old and newly formed internal neural networks as the immigran develops a 'third individuation'. ${ }^{16}$ When these are activated there is a matching reverberation between inner and outer, creating a feeling of belongingness and acknowledgement

\section{VIEWING PSALM 137 THROUGH THE LENS OF THE NEURO-PSYCHOLOGICAL IMPERATIVE}

After this rather lengthy introduction to the neuro-psychological imperative it is now time to turn to Psalm 137 and to view it through this lens. General consensus exists amongst commentators on both the formal poetic beauty of Psalm 137 as well as its effective and affective articulation of the terrible loss due to the exile experience; this is so in spite of the horrible end, the call for the brutal extermination of the enemy infants. It is a poem consisting of three clearly demarcated stanzas comprising two, one and two strophes respectively (Stanza I: vv. 1-4 [2 strophes: vv. 1-2; vv. 3-4,]; Stanza II: vv. 5-6 [1 strophe: vs. 5-6]; Stanza III: vv. 7-9 [2 strophes: vv. 7; vv. 8-9]). Psalm 137 also exhibits a concentric structure with the beginning and end forming an inclusio (e.g. reference to Babel in vv. 1 and 8; see Allen 1983:240) with a strong focus on the centre stanza (vv. 5-6). Commentators refer to this centre stanza as a Zion hymn of a strange kind, which formally also exhibits a chiastic structure. In the centre lies its main thrust of a passionate longing for (i.e. a restored) Zion (Clifford 2003:274, 276; Brueggemann 1984:74). It is compiled of three Gattungen overlapping with the three stanzas: it opens with a communal lament, proceeds to the special kind of Zion hymn presented in the form of a self-imprecation or oath and ends with an imprecation against Judah's archrivals. Prinsloo (2000:286) therefore describes the whole of the psalm as a Mischgattung. In spite of its different sections, there is consensus that the psalm forms a coherent and persuasive unity with probably only vv. $8 \mathrm{c}$ as a later redactional addition (Prinsloo 2000:288). The first stanza represents a looking back at the time in Babel, probably from Jerusalem, still in ruins, before the rebuilding of the temple (537-515 BCE) ${ }_{1}^{17}$ so as to make sense of the strong imprecation against the responsible perpetrators, especially Edom and Babel. It is likely that the poet could have been a Levitical temple singer (vv. 5-6) (Ahn 2008:282; Anderson 1974:897).

Cesar Garza-Guerrero (1974) provides a neat link between the despair of Psalm 137 and culture shock. Culture shock is usually marked by three phases immigrants or exiles go through, namely cultural encounter, reorganisation and a new identity (as is the case for mourners). ${ }^{18}$ The shock of the initial cultural encounter is described as follows:

Subjectively the experience is one of puzzlement ... an admixture of feelings of ... anxiety, sadness, hostility, desperation, a yearning to recover what was lost ... reminiscent of the mourning related to the death of a loved object ... Hand in hand ... a growing sensation

16.A third individuation refers to the establishment of a new hybrid identity after the immigrant has regressed, because of culture shock, to two earlier (psychoanalytical) phases of mother-child separation and adolescence (Ahktar 1995).

17.Ahn (2008:273-274), always substantiating his arguments for precise historical detail, may be too 'precise' in terms of what the psalm really offers, for instance, the exact dating thereof before 582 BCE. See for example Anderson (1972:897), whose dating seems more acceptable.

18.In terms of mourning, the three phases can be subdivided so that the mourning process comprises shock, lamentations, withdrawal, frustration, panic, depression, detachment, adaptation, reinvestment and growth; (see e.g. Flatt 1987:143-148). of discontinuity of identity emerges. It is as if out of his usual habitat, the newcomer no longer has the necessary corroborative environmental feedback for his ego identity.

(Cesar Garza-Guerrero1974:418)

Psalm 137 remains predominantly within the first phase of shock, perhaps with a little reorganisation but certainly not a new identity. Its ideology remains staunchly Zionistic! Brueggemann (1984:51-121) correctly regards the psalm as one of disorientation and a psalm overflowing with emotions, '... van de schoonste door zijn sterke emoties ... van diep-weemoedige herinnering tot national-religieuze trots en dan tot toorn en grimmige wraaksucht' (Gemser 1968:199).

In the first stanza (vv. 1-4) the exiles find themselves in 'ondersteboland' (Burden1991:124) where their neural networks cannot work properly because they were formed and 'conditioned' in Jerusalem. The physical Jerusalem where they could savour its towers, its ramparts and its citadels (Davidson 1998:440), where they could celebrate its festivals in the temple with accompanying smells of daily offerings, hear familiar voices of priests and fellow citizens speaking their language and feel warmed inside by the familiar and loved sounds of temple musicians and choirs as they perform Zion songs, is no more. Only bittersweet memories ${ }^{19}$ remain as the exiles deliberately recall (זכר (זכר (20 $^{20}$ Zion or Jerusalem while they sit weeping. Their inner worlds have no match here in the strange and foreign land of Babel (v. 4) 21 $^{21}$ with its flat surfaces and covered with canals from the Euphrates and Tigris rivers, lined with Euphrates poplars (Eaton 2005:454). The only sounds they hear are sad ones, those of their fellow mourners (v. 1), or the agitating voices of their captors, ${ }^{22}$ mocking them in a foreign language to sing a song of Zion (v. 3). In Jerusalem they were people of status, the elites of society, here they are 'irrigation ditch diggers' (Ahn 2008:280). Along with other captives they are forced to do corvée labour which entails cleaning the canals preventing it from salinisation (Ahn 2008:277-278, 280). Their symbolic world is also shattered, Zion is in ruins and so their faith and hope. They have lost their identity and security, there is nothing in these new surroundings to confirm and acknowledge their inner distinctive selves (Allen 1983:236; Ahn 2008:278-280; Davidson 1998:440; Zenger 1996:48).

The emotional reaction to the loss of the opening verses is that of utter sadness. ${ }^{23}$ This is also one of the typical first reactions during

19.Allen (1983:241) captures the interacting of memories and emotions with the expression of 'bittersweet memories', as emotions are evoked, not only through direct experience but also through recall; see again Manstead (2008:xxix and footnote 12). As is the case with emotion, memory is a complex phenomenon: "The term memory is an inclusive one that deals with our ability to acquire and 'The term mo ability to acquire and retain information [encode], to recall it when needed [retrieve], and to recognize its familiarity when we see it or hear it again [cognize]' (Wingfield \& Byrnes 1981:17). Wingfield and Byrnes (1981:4) also state that memory cannot be seen and has never been seen and to ask where it is located in the brain is to ask where running is located in the body' (Suprenant \& Neath 2009:19). The debate is ongoing whether memory should be theoretically viewed through the systems or structure approach (implies different memory 'storehouses'/structures: 'short term memory' e.g. procedural memory, perceptual representation system, working memory; 'long term memory' - e.g. semantic and episodic memory), or the process approach (the processing of memory layers from shallow to deep), or a 'principles of memory' approach similar to empirically testable bodily regularities (the cue-driven principle, encoding-retrieval principle, cue overload principle, reconstruction principle, impurity principle, relative distinctiveness principle and specificity principle, all define memory) (see Suprenant \& Neath 2009:1-25).

20.Voluntary or willful memory in all three stanzas of Ps 137 (v. 1 - remembering Zion; v. 5 - not forgetting Jerusalem; v. 7 - appeal to Yahweh to keep alive the memory V. 5 - not forgetting Jerusalem; $v .7$ - appeal to Yahweh to keep alive the memory
of the terrible 'day of Jerusalem') is the opposite of involuntary memories which are cue-triggered and uncontrollable, they just appear (see Mace 2007).

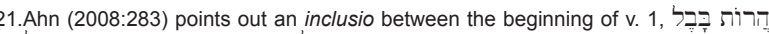

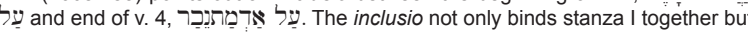
also emphasizes the strangeness of this land.

22.Ahn (2008:281-282) argues that there could have been other corvée labourers working side by side with the Judeans (Anatolians, Syrians, Phoenicians, Egyptians, Tyrians), confirmed by the second hapax legomenon in v. 3, פוֹלָל ינוּ ('our tormentors'), whilst the first, שור 'שרינו ('our captors'), refers to the Babylonians. Could the poet perhaps be so sophisticated that he uses these two hapax legomena to subtly emphasize the 'strangeness' of Babel?

23.Brueggemann (1984:75) refers to the elongated emotional suffering of the exiles as a 'long haul' as if it would never end. Ekman (2008:108), however, points out that emotions are rather short, they last for a few seconds or minutes but are repeatedly evoked so that they are experienced as never ending. 
bereavement where the bereaved is struck with passivity and numbness. Allen points out that this opening lament is akin to the funeral lament (Allen 1983:239, following Kellerman). ${ }^{24}$ The sitting and weeping 25 in v. 1 is the typical posture of mourning (Briggs \& Briggs 1907:485; Dahood 1970:269). The impossibility of singing or playing musical instruments, the latter themselves a visual display of deep sorrow as they hang silently on the trees (Schaefer 2001:321) and moreover, the complete refusal of singing a song of Zion or Yahweh on unholy ground, all vividly capture the exiles' sorrow. The poet also underlines the atmosphere of death with sound play, ' $u$ '- assonance (first person plural endings, vv. 1-3) as well as 's'- alliteration (v. 2) (Allen 1983:241; Prinsloo 2000:283-284). The parallelism of the first two lines repeats the place of their pain (see שָ in v. 1 and

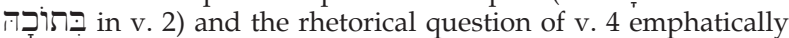
denies any joy. As we have seen, emotions always need objects. The loss mourned by the exiles is for (ruined) Jerusalem, their beloved and personified symbol '... which gave identity and security ...' (Allen 1983:239, citing Brueggemann).

In stanza II, vv. 5-6, the poet switches to the first person singular to present this hymn of complete allegiance to his beloved Jerusalem. Jerusalem is addressed as a person and elevated to something very special. This is done by way of calling a curse upon himself, that he may forever lose his ability as a temple musician to perform on the harp ('may my right hand wither') and to sing ('may my tongue cling to my palate'), should he forget her. ${ }^{26}$ There is an acceptance of the small emendation of תחכ חָש in v. 5 (right hand 'wither' instead of 'forget'); nevertheless, the wordplay still retains between these words (Prinsloo 2000:282; Anderson 1972:899). With the conspicuous chiasm that vv. 5-6 forms, the poet also formally underlines the solemnity of this oath of keeping Jerusalem alive through memory and hope. We find a mixture of emotions in this stanza, namely a tone of anger through the cursing of the self, but then also joy and pride in Jerusalem, symbolising his ultimate delight. Still within the ambit of mourning found in the previous stanza, this stanza too reminds one of '... a yearning to recover what was lost', a '... reactivation in fantasy of past good object relations ...' (Cesar Garza-Guerrero 1974:418, 426). This is a clear example of the first stages of bereavement, of not letting go of the deceased. In foreign Babylonia the fond memory of beloved Jerusalem becomes an anchor and a glimmering hope of its future restoration! Here, there is no question of the further stages of bereavement: detachment, acceptance of the loss and a proceeding to a readjustment or adaptation and new identity (Flatt 1987). The keeping alive of Jerusalem through memory and hope, in a sense, resembles 'micro-copying' of the familiar, a desperate measure to abide with the neuro-psychological imperative to keep it actively 'firing'. This oath sounds like the utterances of some people who have become widowed and vow not to remarry to keep the memory of the deceased alive.

Moving on to the neurological basis of identity, Wexler (2006:192) points out how people unquestioningly invest in the manufacturing of ceremonial objects, often more in terms of time, money and effort than in the making of utilitarian objects. Why is this so? Ceremonial objects and the building of structures on community level serve as '... external manifestation of an internal belief ...' and are therefore sincerely valued! Wexler (2006) highlights the clash of cultures between Eastern Orthodox Christians and Muslims in Cyprus where the former bowed and kissed their religious icons, to the utter dismay of the Muslims:

24.Dahood (1970:270) captures the atmosphere of death as follows: 'The moral inability of the Israelites to sing hymns of praise in Babylonia put them in a class with the denizens of the nether world whose keenest sorrow was their inability to sing Yahweh's praises' (see also Eaton 2005:455; Weiser 1962:794).

25.See again footnote 12 where it is pointed out that emotions are also experienced bodily.

26.Zenger (1996:49, following Hartberger) offers another interpretation than the commonly accepted one. In oath swearing the right hand is on the throat and will automatically strangle the oath taker if not serious. In the immediate context, will automatically strangle the oath taker if not serious. In the immediate context,
however, the losing of the playing and singing abilities of the speaker makes better sense.
What is represented is the inner nature, belief systems, and neurocognitive structures of the human creators of the icons, and it is the direct consonance of the internal and the external that is celebrated and reassuring.

(Wexler 2006:226)

This fixation on the symbol or icon Jerusalem, the provider of identity and security as God's dwelling place and her consequential, ultimate elevation therefore makes sense neuropsychologically. She reconfirms the exiles' internal world and inner selves and provides her adherents with a counterculture stance (Brueggemann 1984:76) against hateful Babylonia to which the psalm finally proceeds.

When the foreign culture, however, is so different that it cannot be accommodated in the own culture, where its presence is a constant agitation so that the '... elimination of ... the offensive presence of difference' (Wexler 2006:211) comes rather naturally, we see the neuro-psychological imperative at work. It is this imperative that fuels the emotion of anger which leads to the call for the extermination of Judah's arch-enemies, Edom and Babylonia, in Stanza III, vv. 7-9. Ethnic cleansing, even in the brutal way of shattering infants' heads against rocks as proposed here in Psalm 137, is not a peculiar Old Testament or ancient Mediterranean pre-civilised way of solving conflict (see 2 Ki 8:12; Is 13:16; Hos 14:1; Nah 3:10). It is a universal human phenomenon where the brutal clashes of cultures confirm the irreconcilability of inner worlds and external realities and explains why, also in modern times, we had a Holocaust during World War II and towards the end of the twentieth century a Rwanda, a former Yugoslavia and probably more to come in the twenty-first century. The anger driven extermination of the hateful enemy ironically reconfirms and reestablishes the beloved own or self. ${ }^{27}$ Neuro-psychological antagonism might not be the only reason for these deadly ideological battles as social, political, historical and economic factors also form part of the motivations for conflict (Wexler 2006:231), but is an inner demanding force that cannot be ignored.

Exile and bereavement are very similar in terms of the experience of loss. Here the neural pathways become confused and frustrated and the emotion of deep-seated anger comes to the fore quite naturally. Attend to Janet Eells' (1977) perceptions on anger during mourning:

Other emotions crowd in. There is anger-anger at the doctors who failed to save the loved one, anger at others who still have their mates or children, anger at God for permitting such a thing to happen, anger at anyone who is around for anything at all.

(Eells 1977:117)

The imperative for Yahweh to 'remember' Edom in v. 7 is the retaliation for the repeated imperatives, עִרִוּ עָרוּ, of this 'brother' - enemy of Judah who incited Jerusalem's destruction in 586 BCE, on her 'day' (Lam 4:21; Ezek 25:12; 36:5; Obad 1014; see Schaefer 2001:321). This is a befitting example of episodic memory (also present in the first two stanzas) where a past experience is recalled in detail in its specific context in time and place. ${ }^{28}$ In this case, it comprises all the gruesome deeds committed against the Judeans on Jerusalem's 'day' and the obvious accompanying anger it evoked then and through recall later on. Emotion-laden events are more likely to be remembered than neutral everyday events as if ingrained in victims' minds

27.Anger, when it avenges itself in this brutal way is the repairing of one's (or the group's) demeaned ego identity (see Lazarus 2008:45, 63).

28. The difference with the other long term memory structure, semantic memory, which is not context bound, is explained by Wingfield \& Byrnes (1981:86) as follows: When you had your breakfast and what you ate today is typical of episodic memory. Your knowledge of what an egg is, and where it comes from, is something stored in ' semantic memory. "Christianson \& Enger misodic mere event is usually better recalled than information on the periphery. 
(Christianson \& Engelberg 2006:65-69). ${ }^{29}$ To add insult to injury, the imperatives also have the connotation of stripping Jerusalem naked, as one would a prostitute, to humiliate them (see Ezek 16:37; Lam 1:8). ${ }^{30}$ Daughter Babylon, v. 8, is the anti-symbol of beloved Jerusalem, representing its exact opposite ideological pole, here and later on $(\operatorname{Rev} 17,18)$, and therefore rightly called 'destructor' ${ }^{31}$ Both the wisdom beatitudes, the יפש statements in vv. 8-9, ironically evoke retributive justice: to pay back Babel justly as well as exterminating her future generations (Zenger 1996:50). ${ }^{32}$

Most commentators are understandably uncomfortable with the 'barbaric' imprecatory note on which Psalm 137 ends and try to get closure for the psalm in different ways to make it usable today. It is argued that it should not be taken literally, but rather interpreted as an understandable outburst of uncontained emotion (Schaefer 2001:323; Ahn 2008:285). Some view Psalm 137 as a call for Zionism but without militarism (e.g. Brueggemann 1984:74). Zenger (1996:500) and many others argue that vengeance should be left in God's hands to restore world order against the destroyers thereof. ${ }^{33}$ Clifford (2003:276) suggests that those that pray today should rather leave out the last verse of the psalm. Some put forward the unthinkable, 'It is wise to read Jeremiah 29 and Psalm 137 side by side' and accommodate and integrate the enemy ideology as many Jews have successfully done and even flourished in the Diaspora (Davidson 1998:442; see also Eaton 2005:456). Answers to the solving of these inner-worldly ideologies that mismatch external realities are not gained easily. The brutal solution provided by Psalm 137, cannot be followed by modern civilised people - violence only breeds more violence. This, however, does not imply that our neurological imperatives should be ignored. Psalm 137 might be wrong in its solutions but is not wrong in its deep-seated neurological or ideological experiences of the 'other.' It is irresponsible to ignore or suppress these feelings because the suppressing of emotions during bereavement leads to even greater emotional suffering later on. It is also not a solution to piously and passively leave things in God's hands which often has the same effect as ignoring the demands of our established neural circuitry. It requires our own responsible hard work to literally 'grow a new brain' to hopefully discover a new consonance between a newly formed inner imperative and the new demanding outer reality within which we find ourselves.

\section{CONCLUSION}

The neuro-psychological imperative provides an apt understanding of the human search for an ego identity during childhood and the assertion of this established 'self' during adulthood. As social beings we first form neuro-psychological internal worlds stimulated and shaped by the whole physical and mental array of our external environment and so acquire an internal-external match. Only afterwards can we live fulfilled lives as we maintain neuro-environmental consonance (Wexler 2006:18). We are 'driven' to continuously match the internal and the external. Emotions provide us with strong driving forces to uphold this consonance and can even inspire physical violence to defend and maintain our internalised ideologies and convictions, our and our group's 'selves'. Part of our neuro-psychological make-up, to a certain extent, 'dies' when

29. They do, however, also point out that utterly traumatic experiences can block out memory, for instance amnesia in both victims and perpetrators.

30. יסוֹד' 'foundations' can also mean 'buttocks' (Dahood 1970:273).

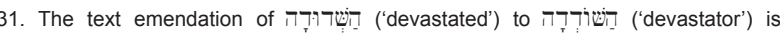
accepted; Note also the ' $\mathrm{s}^{\prime}-$ - alliteration in v. 8 (Dahood 1970:273; Prinsloo 2000:282)

32. The redactional addition, v. 8c, ironically increases the hatred for Babel and for her to be justly punished; see Prinsloo (2000:289).

33.Viviers (2005:799-808), however, points out that God, who can be many things, is markedly also part of people's cultural ideologies and it is often people's god(s) that 'tells' them to commit ethnocide. the internal and external match breaks down, as, for instance, in situations of bereavement and immigration. Our neura networks become deprived of the necessary stimulation and this explains the intensity of our emotional disarray in times of loss. It requires hard work to 'cultivate' a new internal world through new neural networks to match a newly external world.

The tenacity and intensity of the loss of their home countries in stories like that of the Polish immigrant Eva Hoffmann and of the Judean exiles in Psalm 137, become quite transparent when viewed through the lens of the neuro-psychological imperative. The loss of their homeland is not only similar to the death of a loved one, it is their 'own death,' that of their internal worlds that explains the utter pathos of their situations. Therefore, when anger creeps in towards the end of Psalm 137, it should not be seen as something unnatural or unexpected. One of the pressing issues faced by humans today is that anger is not the problem here, but rather the canalising thereof.

\section{REFERENCES}

Ahktar, S., 1995, 'A third individuation: Immigration, identity, and the psychoanalytic process', Journal for the American Psychoanalytic Association 13(4), 1051-1084.

Ahn, J., 2008, 'Psalm 137: Complex communal laments', JBL 127(2), 267-289.

Allen, L.C., 1983, Word Biblical Commentary 21: Psalms 101-150, Word Books, Waco.

Anderson, A.A., 1972, New Century Bible: The Book of Psalms, Vol. 2, Psalms 73-150, Oliphants, London.

Barrett, J.L., 2004, Cognitive Science of Religion Series: Why Would Anyone Believe in God?, AltaMira, Walnut Creek.

Briggs, C.A. \& Brigs, E.G., 1907, ICC: The book of Psalms, vol II, T\&T Clark, Edinburgh.

Brueggemann, W., 1984, Augsburg Old Testament Series: The message of the Psalms, Augsburg Publishing House, Augsburg.

Burden, J.J., 1991, Skrifuitleg vir Bybelstudent en Gemeente: Psalms 120-150 [Scripture interpretation for Bible students and the congregation: Psalms 120-150], NG Kerk-Uitgewers, Kaapstad.

Cesar Garza-Guerrero, A., 1974, ‘Culture shock: Its mourning and the vicissitudes of identity', Journal for the American Psychoanalytic Association 22, 408-429.

Christianson, S.Á. \& Engelberg, E., 2006, 'Remembering Emotional Events: The Relevance of Memory for Associated Emotions', in B. Uttl, N. Ohta, \& A.L. Siegenhalter (eds.), Memory and Emotion: Interdisciplinary Perspectives, p. 59-82, Blackwell, Oxford.

Clifford, R.J., 2003, Abingdon Old Testament Commentaries: Psalms 73-150, Abingdon Press, Nashville.

Davidson, R., 1998, The Vitality of Worship: A Commentary on the Book of Psalms, Eerdmans, Grand Rapids.

Dahood, M., 1970, Anchor Bible: Psalms III, 101-150, Doubleday, New York.

Eaton, J., 2005, The Psalms, Continuum, London.

Eells, J., 1977, 'In times of grief', Journal of Religion and Health $16(2), 116-118$

Ekman, P., 2008 [1992], 'An argument for basic emotions', in A.S.R. Manstead (ed.), Sage Benchmarks in Psychology: Psychology of Emotions, vol. 1, p. 95-123, Sage Publications, Los Angeles.

Flatt, B., 1987, 'Some stages of grief', Journal of Religion and Health 26(2), 143-148.

Gemser, B., 1968, De Psalmen [The Psalms], G.F. Callenbach, Nijkerk.

Guthrie, S.E., 1993, Faces in the Clouds: A New Theory of Religion, Oxford University Press, Oxford.

Kagan, J., 1994, 'On the nature of emotion', Monographs of the Society in Child Development 59(2/3), 7-24.

Kuberski, P., 2000, 'A worldly mind: Natural history and the experience of consciousness', Substance 29(1), 7-22. 
Lazarus, R.S., 2008 [1991], 'Progress on a cognitive-motivationalrelational theory of emotion', in A.S.R. Manstead (ed.), Sage Benchmarks in Psychology: Psychology of Emotions, vol. 1, p. 45-75, Sage Publications, Los Angeles.

Leavitt, J., 1996, 'Meaning and feeling in the Anthropology of emotions', American Ethnologist 23(3), 514-539.

Mace, J., 2007, Involuntary Memory: New Perspectives in Memory Research, Blackwell, Oxford.

Manstead, A.S.R., 2008, 'Editor's introduction', in A.S.R Manstead (ed.), Sage Benchmarks in Psychology: Psychology of Emotions, vol. 1, p. xxv-xlix, Sage Publications, Los Angeles.

McCutcheon, R.T., 2000, 'Myth', in W. Braun \& R.T. McCutcheon (eds.), Guide to the Study of Religion, p. 190-208, Cassel, London.

Newberg, A., D'Aquili, E. \& Rause, V., 2001, Why God won't go away: Brain Science and the Biology of Belief, Ballantine Books, New York.

Pyysiäinnen, I., 2001, Cognition and Culture Book Series, Vol 1: How Religion Works: Towards a New Cognitive Science of Religion, Brill, Leiden.
Prinsloo, W.S., 2000 [1988], 'Ecclesia pressa, ecclesia triumphans', in W. Beuken, P. Botha, D. Human, C. Pauw \& G. Prinsloo (reds.), Die lof van my God solank ek lewe, p. 281-293, Medpharm Publikasies, Irene.

Schaefer, K., 2001, Berit Olam: Psalms, The Liturgical Press, Minnesota.

Suprenant, A.M. \& Neath, I., 2009, Principles of Memory, Psychology Press, New York.

Viviers, H., 2005, 'The Politics of Bodily Disability', Scriptura 90(3), 799-808.

Wexler, B., 2006, Brain and Culture: Neurobiology, Ideology, and Social Change, MIT Press, Massachusetts.

Weiser, A., 1962, OTL: The Psalms: A Commentary, SCM, London.

Wingfield, A. \& Byrnes, D.L., 1981, The Psychology of Human Memory, Academic Press, New York.

Zajonc, R., 1970, 'Brainwash: Familiarity breeds comfort', Psychology Today 3(9), 32-35.

Zenger, E., 1996, A God of vengeance: Understanding the Psalms of divine wrath, transl. L.M. Mahoney, Westminster John Knox, Louisville. 